\title{
Risk factors of post renal transplant anaemia among Sudanese patients, a study in three renal transplant centres
}

\author{
Amin SI Banaga ${ }^{1 *}$, Mohamed EA Yousif ${ }^{2}$ and Khalifa Elmusharaf ${ }^{3}$
}

\begin{abstract}
Background: There is a relative lack of recent information about late post kidney transplantation anaemia (PTA), especially in the developing countries; data are scarce about the prevalence and risk factors of PTA. Sudan was a leading country in Africa and Arab world in kidney transplantation. The first kidney transplantation in Sudan was in 1973.

Methods: This is a cross-sectional hospital analytic study enrolling all kidney transplanted recipients following in the transplant referral clinics at Ahmed Gassim, Selma and Ibn Sina Hospitals, Khartoum/Sudan, in the period from 1/8/2010 to 1/9/2010, clinical and laboratory data were obtained from 114 patients, anaemia was defined as $\mathrm{Hb}$ levels of $<13 \mathrm{~g} / \mathrm{dl}$ for male patients and $<12 \mathrm{~g} / \mathrm{dl}$ for female patients, exclusion criteria were pregnancy, below 18 years old patients, multiple organ transplantation, and patients with less than one year from the transplantation.

Results: The study showed that $39.5 \%$ of the patients were anaemic. Univariate analysis showed that late PTA is significantly associated with not using Erythropoietin (EPO) in the pre-transplant period ( $p=<0.001$ ), history of rejection ( $p=0.003)$, longer time from transplantation $(p=0.015)$, and eGFR $(p<0.0001)$. Multivariate analysis showed that eGFR ( $p=<0.001)$ and not use of EPO in the pre transplant period ( $p<0.001)$ are strong predictors of PTA. The use of Angiotensin converting enzyme inhibitors/Angiotensin receptors blockers (ACEI/ARB), immunosuppressive treatments, presence or absence of co-morbidities, donor type and donor age are not significantly associated with late PTA.
\end{abstract}

Conclusion: The study concluded that late PTA is common and under recognized. Risk factors for late PTA include renal dysfunction, history of rejection, longer duration of transplantation and not using EPO in the pre-transplant period. Renal dysfunction and not using EPO in the pre-transplant period are major predictors of late PTA.

Keywords: Sudan, Post transplant anaemia, Erythropoietin

\section{Background}

Anaemia in End Stage Renal Failure (ESRF) is mainly due to loss of the endocrine function of the kidneys that lead to deficiency of erythropoietin (EPO) and development of anaemia. Many studies pointed out the prevalence of Post transplant Anaemia (PTA) in developed countries, a Japanese study concluded that the prevalence of PTA is $20 \%$ [1], a big multicenter study

\footnotetext{
* Correspondence: amin.banaga@gmail.com

'Department of Medicine \& Nephrology, University of Medical Sciences and Technology, Consultant Physician and Head of Haemodialysis Unit, Academy Charity Teaching Hospital, Khartoum, P.O Box. 12810, Sudan

Full list of author information is available at the end of the article
}

conducted in 72 centers in 16 European countries [Transplant European Survey on Anaemia Management (TRESAM)] concluded that the prevalence of PTA was $38.6 \%$ [2]. In a published British study, the prevalence of anaemia was $53 \%$ at 12 months from the kidney transplantation [3]. A Turkish study concluded that prevalence of PTA was 49.3\% [4], in Austria PTA was present in $39.7 \%$ [5]. Among Hungarians, PTA was 33.8\% [6].

Renal dysfunction is strongly associated with development of PTA [2,7-18] and considered as a major risk factor, other risk factors like rejection $[9,19,20]$, recent infections [21-24], longer duration from transplantation [7], immunosuppressive treatments [3,25-32], use of

\section{Biomed Central}


Angiotensin converting enzyme inhibitors/Angiotensin receptors blockers (ACEI/ARB) $[2,12,13,33,34]$, low serum albumin [4], protein energy waste syndrome [35], and old age of the kidney donor [2] are all considered as risk factors for development of PTA.

Our aim in this study is to identify the prevalence of late PTA ( $>1$ year post transplant) and the risk factors of late PTA among adult Sudanese kidney recipients.

\section{Methods}

\section{Study population \& Data collection}

This study is a cross sectional hospital base analytic study. The subjects of the study are all kidney transplanted recipients following in the transplant referral clinics at Ahmed Gassim, Selma \& Ibn Sina Hospitals, Khartoum/Sudan. All patients attending the transplant referral clinics between $(1 / 8 / 2010$ - 1/9/2010) were interviewed by questionnaire focusing on personal and clinical data exploring (time on dialysis, receiving EPO treatment during dialysis, period of transplantation, donor age, immunosuppressive regimen, The use of ACEI/ARB, history of rejection, and presence or absence of co-morbidities) with a review of their medical files. All laboratory investigations conducted at the time of the visit such as (complete blood count, peripheral blood picture, and renal functions) were reported. Estimated Glomerular Filtration rate (eGFR) was calculated using the abbreviated modification of diet in renal disease (MDRD) study formula [36]. The research was in compliance of the declaration of Helsinki and approved by ethics and research committees in the local hospitals, an informed consent was obtained from each patient participated in the study

\section{Haemoglobin target}

Anaemia was defined as $\mathrm{Hb}$ levels of $<13 \mathrm{~g} / \mathrm{dl}$ for male patients and $<12 \mathrm{~g} / \mathrm{dl}$ for female patients this targets were selected based on the WHO guidelines \& the American Society of Transplantation [37].

\section{Inclusion \& exclusion criteria}

We included all kidney transplant recipients who received a kidney transplant and attended the referral clinic at Ahmed Gassim, Selma and Ibn Sina Hospitals between $1 / 8-1 / 9 / 2010$. The exclusion criteria were Pregnancy, below 18 years old patients, multiple organ transplantation and patients with less than 1 year from the transplantation.

\section{Statistical analysis}

Categorical variables between the anaemic and non anaemic patients were compared using $X^{2}$ test, continues variables between the anaemic and non anaemic patients were compared using Student T-test.
Multivariate linear regression analysis used to identify the predictors of PTA. Statistical analysis conducted using SPSS 18 software package (SPSS Inc, Chicago, IL, USA) and $\mathrm{P}$ value $<0.05$ were considered significant.

\section{Results}

The characteristics of the study population are shown in Table 1. Our result showed that the prevalence of late PTA was $39.5 \%$ of all Sudanese kidneys transplanted patients. Prevalence of anaemia in Ibn Sina centre was $38.7 \%$, Selma centre was $38.5 \%$ and Ahmed Gassim centre was $40 \%$

A univariate analysis of risk factors associated with late PTA showed that anaemia is significantly associated with not using EPO in pre-transplant period $(\mathrm{p}<0.001)$, History of rejection was also associated with PTA ( $\mathrm{p}=$ $0.003)$, eGFR $(\mathrm{p}<0.0001)$ and long period from transplantation $(\mathrm{p}=0.015)$. No significant relation was found between anaemia and age, time on dialysis, donor age, immunosuppressive treatments, presence or absence of co-morbidities, ACEI/ARB and gender (Table 2).

Multivariate analysis conducted by linear regression analysis for risk factors of late PTA, using haemoglobin as dependant variable, in the linear regression model $(r=$ 0.626, $p=<0.0001)$ eGFR $(\mathrm{p}<0.0001)$ and not using

Table 1 The characteristics of the study population

\begin{tabular}{|c|c|}
\hline Recipient gender ${ }^{a}$ & $\begin{array}{l}\text { Male } 78(68.4 \%) \\
\text { Female } 36(31.6 \%)\end{array}$ \\
\hline Recipient age ${ }^{b}$ & $42.4 \pm 12.66$ \\
\hline Occupation $^{a}$ & $\begin{array}{l}\text { Unemployed } 81(71.1 \%) \\
\text { Non professional } 16(14 \%) \\
\text { Professional } 17(14.9 \%)\end{array}$ \\
\hline Donor type $^{a}$ & $\begin{array}{l}\text { Living related donor: } 99 \\
(86.8 \%) \\
\text { Living unrelated: } 15 \text { (13.2\%) }\end{array}$ \\
\hline History of acute rejection ${ }^{a}$ & Yes 13 (11.4\%) No 101 (88.6\%) \\
\hline$\overline{\text { Donor age }(\text { years) }}{ }^{\mathrm{b}}$ & $28.9 \pm 7.6$ \\
\hline Use of EPO pre-transplant ${ }^{a}$ & Yes 64 (56.1\%) No 50 (43.9\%) \\
\hline Use of Mycofenolate mofetil ${ }^{a}$ & Yes 31 (27.2\%) No 83(72.8\%) \\
\hline Use of Azathioprine ${ }^{a}$ & Yes 80 (70.2\%) No 34 (29.8\%) \\
\hline Use of Cyclosporine ${ }^{a}$ & Yes 45 (39.5\%) No 69 (60.5\%) \\
\hline Use of Tacrolimus ${ }^{a}$ & Yes 65 (57\%) No 49 (43\%) \\
\hline Use of $A C E I / A R B^{a}$ & Yes 23 (20.2\%) No 91 (79.8\%) \\
\hline Co-morbidities & Yes 9 (7.9\%) No 105 (92\%) \\
\hline Time on Dialysis (months) ${ }^{b}$ & $14.6 \pm 13$ \\
\hline $\begin{array}{l}\text { Period of kidney transplantation } \\
\text { (months) }^{\mathrm{b}}\end{array}$ & $49 \pm 42.26$ \\
\hline $\mathrm{Hb} \mathrm{g/dl^{b }}$ & $12.7 \pm 1.96$ \\
\hline Creatinine $\mathrm{mg} / \mathrm{dl}^{\mathrm{b}}$ & $1.4 \pm 0.88$ \\
\hline Urea $\mathrm{mg} / \mathrm{dl}^{\mathrm{b}}$ & $39.17 \pm 19.5$ \\
\hline$\overline{\mathrm{eGFR} \mathrm{ml} / \mathrm{min} / 1.73^{2} \mathrm{~b}}$ & $81.6 \pm 34.3$ \\
\hline
\end{tabular}

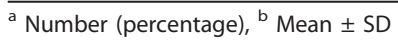


Table 2 Risk factors of post transplant anaemia

\begin{tabular}{|c|c|c|c|}
\hline & $\begin{array}{c}\text { Anaemic group } \\
N(45)\end{array}$ & $\begin{array}{c}\text { Non anaemic group } \\
N(69)\end{array}$ & $P$ value \\
\hline $\mathrm{Age}^{\mathrm{b}}$ & $42.9 \pm 12.9$ & $42 \pm 12.7$ & 0.7 \\
\hline$\overline{\text { Gender }(M / F)^{a}}$ & $31 / 14$ & $47 / 22$ & 0.93 \\
\hline Use of (EPO) pre transplant ${ }^{a}$ & $12(18.8 \%)$ & $52(81.3 \%)$ & $<0.0001$ \\
\hline $\begin{array}{l}\text { Donor type }^{a} \\
\text { Living related }\end{array}$ & $38(38.4 \%)$ & $61(61.6 \%)$ & 0.54 \\
\hline Living unrelated $^{a}$ & $8(53.3 \%)$ & $7(46.7 \%)$ & \\
\hline History of rejection ${ }^{a}$ & $10(76.9 \%)$ & $3(23.1 \%)$ & 0.003 \\
\hline Use of Mycofenolate mofetil ${ }^{a}$ & $10(32.3 \%)$ & $21(67.7 \%)$ & 0.33 \\
\hline Use of Azathioprine ${ }^{a}$ & $33(41.2 \%)$ & $47(58.8 \%)$ & 0.55 \\
\hline Use of Cyclosporine ${ }^{a}$ & $22(48.9 \%)$ & $23(51.1) \%$ & 0.09 \\
\hline Use of Tacrolimus $^{a}$ & $21(32.3 \%)$ & $44(67.7 \%)$ & 0.07 \\
\hline Use of $A C E I / A R B^{a}$ & $8(34.8 \%)$ & $15(65.2 \%)$ & 0.6 \\
\hline Presence of Co-Morbidities & $2(22.2 \%)$ & $7(77.8)$ & 0.27 \\
\hline Time on dialysis (months) ${ }^{\mathrm{b}}$ & $12.9 \pm 11.6$ & $15.7 \pm 13.8$ & 0.26 \\
\hline Time since transplantation (months) ${ }^{b}$ & $62.1 \pm 51.5$ & $40.5 \pm 33.02$ & 0.015 \\
\hline Donor age (years) ${ }^{b}$ & $29.3 \pm 7$ & $28.5 \pm 8$ & 0.6 \\
\hline eGFR $\left(\mathrm{ml} / \mathrm{min} / 1.73^{2}\right.$ & $56.8 \pm 20.7$ & $97.7 \pm 31.8$ & $<0.0001$ \\
\hline
\end{tabular}

EPO in the pre-transplant period ( $\mathrm{p}<0.0001)$ significantly predict anaemia among kidney recipients (Table 3 )

\section{Discussion}

Prevalence of Late PTA

Published literature on PTA is limited, especially in developing countries, this is due to lack of transplantation facilities which lead to deficiency on PTA published data, this study is the first Sudanese study on prevalence and risk factors of late PTA. Our result showed that $39.5 \%$ of kidney transplanted patients have anaemia. This high prevalence indicates the severity of this problem among Sudanese renal transplanted population; our result is higher than many of the published literature in the developed countries. Prevalence of PTA in Japan is $20 \%$ [1]. In other American study it was $26 \%$ in 5 years post transplant [7]. In the European TRESAM study it was $38 \%$ [2]. In Austria, PTA was present in

Table 3 Liner regression model of serum haemoglobin as dependant variable $(r=0.626, p=<0.0001)$

\begin{tabular}{lccc}
\hline Variable & $\boldsymbol{\beta}$ & $\boldsymbol{t}$ & $\boldsymbol{P}$ value \\
\hline Age & -0.008 & -0.097 & 0.923 \\
\hline Gender & 0.058 & 0.731 & 0.466 \\
\hline eGFR & 0.381 & 4.563 & $<0.0001$ \\
\hline Presence or absence of Co-morbidities & -0.064 & -0.822 & 0.431 \\
\hline Time since transplantation & -0.031 & -0385 & 0.701 \\
\hline History of rejection & -0.123 & -1.608 & 0.111 \\
\hline Use of EPO & 0.376 & 4.736 & $<0.0001$ \\
\hline
\end{tabular}

39.7\% [5]. Among Hungarians, PTA was 33.8\% [6]. In other hand data published from Asia and South America showed higher prevalence of PTA, in Turkey PTA was present among $49.3 \%$ of transplanted patients [4], PTA in Argentina was 42.2\% [38].

\section{The characteristics of the study population}

In our study, we reviewed 114 patients, $68 \%$ were males, Live related donors constitute $86.6 \%$ of the donor type with no cadaveric donors in our study population; this is very different from the other major published literature from the developed countries where cadaveric donors are the major donor type in kidney transplantation. $43.9 \%$ of this study population didn't receive EPO during dialysis because of financial reasons which reflects poor management of anaemia among our patients in the pre-transplant period. The mean age in this study was 42 years. Only 9 patients have co-morbidities mainly (Liver diseases, Diabetes mellitus and Heart diseases). Despite that renal transplantation improves the quality of life of the patients; unemployment rate is high among kidney recipients $71.1 \%$

\section{Risk factors for PTA}

After univariate analysis of the variables, history of rejection was associated with anaemia $(\mathrm{p}=0.003)$, this result agrees with many of published articles which stated that rejection is a leading cause for anaemia $[9,19,20]$.

Renal dysfunction was strongly associated with anaemia; in our study, anaemic patients have mean of eGFR 
of $56 \mathrm{ml} / \mathrm{min} / 1.73^{2}(\mathrm{p}=<0.0001)$, this result is going with the majority of published literature on PTA suggesting renal dysfunction as major cause of PTA [2,7-18].

Patients with longer duration of transplantation have more tendency to develop late PTA $(\mathrm{p}=0.015)$, this is agrees with many literature which pointed out the increase prevalence of anaemia in the late post-transplant period in comparison with early post-transplant period [7], this is also can be explained by the fact that chronic allograft nephropathy can occur after long time from transplantation and that may lead to development of PTA.

In this study not using of EPO before transplantation was a major risk factor for PTA ( $<<0.0001)$, so patients may still have significant anaemia at time of transplantation. Use of EPO pre transplant is associated with better 5 year graft survival and reduce frequency of rejection [39], concerning the level of EPO in the post transplant period, in a study compared two groups (anaemic \& non-anaemic) of renal transplant recipients with normal renal functions, EPO deficiency and resistance play a causative role for PTA [40], however in other study no relation was found between administration of the EPO and anaemia, the same result favoring use of EPO only on high risk patients [41].

Multivariate analysis showed that renal dysfunction and not using EPO before transplantation were major predictors for PTA.

In this result, immunosuppressive treatment was not associated with anaemia this is contradicting with the majority of the literature which stating the strong relationship [3,25-32], however another study found no relation between anaemia and some combinations of immunosuppressive treatments [2] and perhaps live related transplantation needing less immunosuppressive treatments may be the curl print point.

In this study there was no relation between ACEI/ARB and late PTA, the literature concerning that is controversial with some favoring the link between PTA and ACEI/ARB $[2,12,13,33,34]$ and other articles denied the relationship [15,17].

Our study had many limitations that need to be recognized, we didn't have data on iron stores and serum albumin this is mainly due to lack of financial recourses, medical data about the exact nature and details of comorbidities was difficult to obtain, so we just asked our patients about nature and presence or absence of co morbidities. Data about numbers and treatment of rejection and history of blood transfusions was not collected.

\section{Conclusion}

The study concluded that late PTA is common and under recognized. Risk factors for late PTA include renal dysfunction, history of rejection, longer duration of transplantation and not using EPO in the pre-transplant period. Renal dysfunction and not using EPO in the pre-transplant period are major predictors of PTA.

\section{Acknowledgements}

The authors thanks the patients and the staff in Ahmed Gassim, Ibn Sina and Dr. Selma hospitals, Khartoum, Sudan, for contribution in this study,

\section{Author details}

'Department of Medicine \& Nephrology, University of Medical Sciences and Technology, Consultant Physician and Head of Haemodialysis Unit, Academy Charity Teaching Hospital, Khartoum, P.O Box. 12810, Sudan. ${ }^{2}$ Department of Nephrology, Ibn Sina Hospital, Dr. Selma Centre for Kidney Diseases, Consultant Physician and Nephrologist, Head of the Renal Transplantation Team at Ibn Sina Hospital, Khartoum, Sudan. ${ }^{3}$ Connecting Health Research in Africa \& Ireland Consortium 'ChRAIC', PhD Researcher Health System \& Policy, Department of Epidemiology, Royal College of Surgeons, Ireland.

\section{Authors' contributions}

ASIB designed the questionnaire, collected the sample, carried out the study, analyzed the data, and drafted the manuscript. MEAY directed the study, drafted and revised the manuscript. KE revised the methodology, statically analyzed the data and revised the manuscript. All authors read and approved the final manuscript

\section{Competing interests}

The authors declare that they have no competing interests.

Received: 29 March 2011 Accepted: 9 August 2011

Published: 9 August 2011

\section{References}

1. Saito S, Fujiwara T, Sakagami K, Matsuno T, Tanaka N: Anemia following renal transplantation. Transplant Proc 1998, 30(7):3025-3026.

2. Vanrenterghem Y, Ponticelli C, Morales JM, Abramowicz D, Baboolal K, Eklund B, Kliem V, Legendre C, Morais Sarmento AL, Vincenti F: Prevalence and management of anemia in renal transplant recipients: a European survey. Am J Transplant 2003, 3(7):835-845.

3. Borrows R, Loucaidou M, Chusney G, Borrows S, Tromp JV, Cairns T, Griffith M, Hakim N, McLean A, Palmer A, et al: Anaemia and congestive heart failure early post-renal transplantation. Nephrol Dial Transplant 2008, 23(5):1728-1734

4. Unal A, Sipahioglu MH, Akcakaya M, Tokgoz B, Sav T, Oymak O, Utas C: An underappreciated problem in renal transplant recipients: anemia. Transplant Proc 2008, 40(5):1399-1403.

5. Lorenz M, Kletzmayr J, Perschl A, Furrer A, Horl WH, Sunder-Plassmann G: Anemia and iron deficiencies among long-term renal transplant recipients. J Am Soc Nephrol 2002, 13(3):794-797.

6. Molnar MZ, Czira M, Ambrus C, Szeifert L, Szentkiralyi A, Beko G, Rosivall L, Remport A, Novak M, Mucsi I: Anemia is associated with mortality in kidney-transplanted patients-a prospective cohort study. Am J Transplant 2007, 7(4):818-824.

7. Yorgin PD, Scandling JD, Belson A, Sanchez J, Alexander SR, Andreoni KA: Late post-transplant anemia in adult renal transplant recipients. An under-recognized problem? Am J Transplant 2002, 2(5):429-435.

8. Choukroun G, Deray G, Glotz D, Lebranchu Y, Dussol B, Bourbigot B, Lefrancois N, Cassuto-Viguier E, Toupance O, Hacen C, et al: [Incidence and management of anemia in renal transplantation: an observationalFrench study]. Nephrol Ther 2008, 4(7):575-583.

9. Muirhead N: Erythropoietin and renal transplantation. Kidney Int Suppl 1999, 69:S86-92.

10. Shibagaki $Y$, Shetty A: Anaemia is common after kidney transplantation, especially among African Americans. Nephrol Dial Transplant 2004, 19(9):2368-2373.

11. Sezer S, Ozdemir FN, Tutal E, Bilgic A, Haberal M: Prevalence and etiology of anemia in renal transplant recipients. Transplant Proc 2006, 38(2):537-540. 
12. Gentil MA, Perez-Valdivia MA, Lopez-Mendoza M, Ortega F, Arias M, GomezAlamillo C, Campistol JM: Factor deficiency in the anemia of renal transplant patients with grade III-IV chronic kidney disease: baseline results of the ARES Study. Transplant Proc 2008, 40(9):2922-2924.

13. Shah N, Al-Khoury S, Afzali B, Covic A, Roche A, Marsh J, Macdougall IC, Goldsmith DJ: Posttransplantation anemia in adult renal allograft recipients: prevalence and predictors. Transplantation 2006, 81(8):1112-1118.

14. Turkowski-Duhem A, Kamar N, Cointault O, Lavayssiere L, Ribes D, Esposito L, Fillola G, Durand D, Rostaing L: Predictive factors of anemia within the first year post renal transplant. Transplantation 2005, 80(7):903-909.

15. Sinnamon KT, Courtney AE, Maxwell AP, McNamee PT, Savage G, Fogarty DG: Level of renal function and serum erythropoietin levels independently predict anaemia post-renal transplantation. Nephrol Dial Transplant 2007, 22(7):1969-1973.

16. Ott $U$, Busch $M$, Steiner $T$, Wolf G: Anemia after renal transplantation: an underestimated problem. Transplant Proc 2008, 40(10):3481-3484.

17. Molnar MZ, Novak M, Ambrus C, Kovacs A, Pap J, Remport A, Szeifert L, Mucsi I: Anemia in kidney transplanted patients. Clin Transplant 2005, 19(6):825-833.

18. Fernandez Fresnedo G, Palomar R, Rodrigo E, Ruiz JC, de Francisco AL, Cotorruelo JG, Arias M: Prevalence of anemia in renal transplant patients: results from MOST, an observational trial. Transplant Proc 2005, 37(9):3821-3822

19. Moulin B, Ollier J, George F, Purgus R, Roux F, Sampol J, Olmer M: Serum erythropoietin and reticulocyte maturity index after renal transplantation: a prospective longitudinal study. Nephron 1995, 69(3):259-266

20. Chua MS, Barry C, Chen X, Salvatierra O, Sarwal MM: Molecular profiling of anemia in acute renal allograft rejection using DNA microarrays. Am J Transplant 2003, 3(1):17-22.

21. Kumar V, Gupta S, Singh S, Goyal VK, Yadav M: Pure red cell aplasia associated with cytomegalovirus infection. J Pediatr Hematol Oncol 2010 32(4):315-316.

22. So BJ, Chae KM, Lee KK, Lee YJ, Jeong BH: Pure red cell aplasia due to parvovirus B19 infection in a renal transplant patient: a case report. Transplant Proc 2000, 32(7):1954-1956.

23. Vales-Albertos LJ, Garcia-Cardenas M, Chavez-Becerra S, Gomez-Navarro B, Monteon-Ramos F, Cueto-Manzano AM: Pure red cell aplasia associated with parvovirus B19 infection in renal transplantation: the first case report in Mexico. Transplantation 2005, 79(6):739.

24. Karras A, Thervet E, Legendre C: Hemophagocytic syndrome in renal transplant recipients: report of 17 cases and review of literature. Transplantation 2004, 77(2):238-243

25. Kuypers DR, de Jonge $H$, Naesens $M$, de Loor $H$, Halewijck E, Dekens $M$, Vanrenterghem $Y$ : Current target ranges of mycophenolic acid exposure and drug-related adverse events: a 5-year, open-label, prospective, clinical follow-up study in renal allograft recipients. Clin Ther 2008, 30(4):673-683.

26. Engelen W, Verpooten GA, Van der Planken M, Helbert MF, Bosmans JL, De Broe ME: Four cases of red blood cell aplasia in association with the use of mycophenolate mofetil in renal transplant patients. Clin Nephrol 2003, 60(2):119-124.

27. Ourahma S, Mercadal L, Tezenas du Montcel S, Assogba D, Bitker MO, Mallet A, Barrou B: Anemia in the period immediately following renal transplantation. Transplant Proc 2007, 39(5):1446-1450.

28. Geiger C, Foller M, Herrlinger KR, Lang F: Azathioprine-induced suicidal erythrocyte death. Inflamm Bowel Dis 2008, 14(8):1027-1032.

29. Rigatto C: Anemia, renal transplantation, and the anemia paradox. Semin Nephrol 2006, 26(4):307-312.

30. Agrawal A, Parrott NR, Riad HN, Augustine T: Azathioprine-induced pure red cell aplasia: case report and review. Transplant Proc 2004, 36(9):2689-2691.

31. Khosroshahi HT, Asghari A, Estakhr R, Baiaz B, Ardalan MR, Shoja MM: Effects of azathioprine and mycophenolate mofetil-immunosuppressive regimens on the erythropoietic system of renal transplant recipients. Transplant Proc 2006, 38(7):2077-2079.

32. Willerding-Mollmann S, Wilkens L, Schlegelberger B, Kaiser U: [Azathioprineassociated myelodysplastic syndrome with cytogenetic aberrations]. Dtsch Med Wochenschr 2004, 129(22):1246-1248.
33. Naito M, Kawashima A, Akiba T, Takanashi M, Nihei H: Effects of an angiotensin II receptor antagonist and angiotensin-converting enzyme inhibitors on burst forming units-erythroid in chronic hemodialysis patients. Am J Nephrol 2003, 23(5):287-293.

34. Le Meur Y, Lorgeot V, Comte L, Szelag JC, Aldigier JC, Leroux-Robert C, Praloran V: Plasma levels and metabolism of AcSDKP in patients with chronic renal failure: relationship with erythropoietin requirements. Am J Kidney Dis 2001, 38(3):510-517.

35. Molnar MZ, Czira ME, Rudas A, Ujszaszi A, Haromszeki B, Kosa JP, Lakatos P, Beko G, Sarvary E, Varga M, et al: Association between the malnutritioninflammation score and post-transplant anaemia. Nephrol Dial Transplant 2011, 26(6):2000-2006.

36. Levey AS, Greene T, Kusek JW, Beck GL: A simplified equation to predict glomerular filtration rate from serum creatinine (abstract). J Am Soc Nephrol 2000, 11(155A).

37. Kasiske BL, Vazquez MA, Harmon WE, Brown RS, Danovitch GM, Gaston RS, Roth D, Scandling JD, Singer GG: Recommendations for the outpatient surveillance of renal transplant recipients. American Society of Transplantation. J Am Soc Nephrol 2000, 11(Suppl 15):S1-86.

38. Petrone H, Arriola M, Re L, Taylor F, Bruzzone M, Chiurchu C, Schiavelli R: National survey of anemia prevalence after kidney transplantation in Argentina. Transplant Proc 2010, 42(1):288-290.

39. Lietz K, Lao M, Paczek L, Gorski A, Gaciong Z: The impact of pretransplant erythropoietin therapy on late outcomes of renal transplantation. Ann Transplant 2003, 8(2):17-24.

40. Nampoory MR, Johny KV, al-Hilali N, Seshadri MS, Kanagasabhapathy AS: Erythropoietin deficiency and relative resistance cause anaemia in postrenal transplant recipients with normal renal function. Nephrol Dial Transplant 1996, 11(1):177-181.

41. Van Biesen W, Vanholder R, Veys N, Verbeke F, Lameire N: Efficacy of erythropoietin administration in the treatment of anemia immediately after renal transplantation. Transplantation 2005, 79(3):367-368.

\section{Pre-publication history}

The pre-publication history for this paper can be accessed here: http://www.biomedcentral.com/1471-2369/12/37/prepub

\section{doi:10.1186/1471-2369-12-37}

Cite this article as: Banaga et al:: Risk factors of post renal transplant anaemia among Sudanese patients, a study in three renal transplant centres. BMC Nephrology 2011 12:37.

\section{Submit your next manuscript to BioMed Central and take full advantage of:}

- Convenient online submission

- Thorough peer review

- No space constraints or color figure charges

- Immediate publication on acceptance

- Inclusion in PubMed, CAS, Scopus and Google Scholar

- Research which is freely available for redistribution 